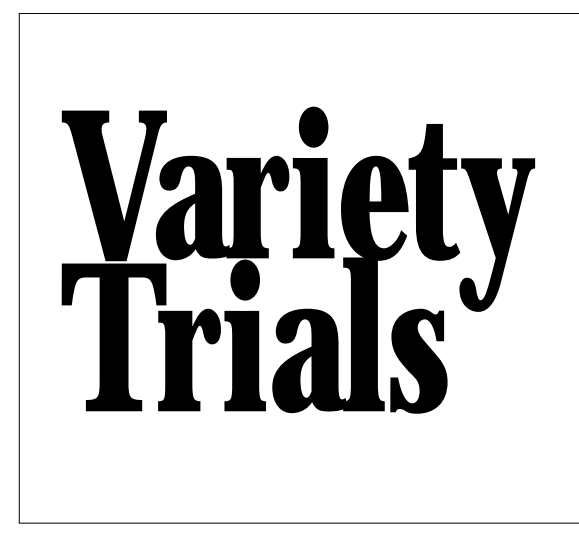

\section{Evaluation and Yield Trials of Tomatillo in New Hampshire}

\author{
Rosanna Freyre ${ }^{1}$ and \\ J. Brent Loy²
}

\begin{abstract}
Summary. Five tomatillo (Physalis ixocarpa B rot. ex $\mathrm{H}$ ornem) cultivars available from commercial seed companies ('D e M ilpa', 'Puebla Verde', 'Purple T omatillo', 'T omatillo' and 'T oma Verde') and four Physalis . accessions (PI 197691, PI 270459, PI 291560, and PI 309812) were grown in 1997 and 1998 at Kingman R esearch Farm, D urham, N.H. Three manual harvests per plot were performed each year, recording data of total fruit weight, number of fruit and average fruit weight for each genotype. There were statistically significant differences between tomatillo genotypes for all three traits. Statistically significant differences between the 2 years were found for fruit number and average fruit weight per genotype. 0 ver both years, total fruit weight varied from 29.7 to $63.7 \mathrm{t} \cdot \mathrm{ha}^{-1}$ (13.3 to 28.4 ton/ acre). Fruit numbers per plant varied from 83 to 330 , and average fruit weight
\end{abstract}

$\overline{\mathrm{N} \text { ew H} \text { ampshire Agricultural Experiment Station sci- }}$ entific contribution 2043. We thank Charles Bornt, Kim M ilbert, and Vikki Rodgersfor technical assistance and many students who helped during harvests. The cost of publishing this paper was defrayed in part by the payment of page charges. U nder postal regulations, this paper therefore must be hereby marked advertise ment solely to indicate this fact.

${ }^{1}$ Research Assistant Professor, Dept. Plant Biology, U niversity of N ew H ampshire, D urham, N H 03824.

${ }^{2}$ Professor, Dept. Plant Biology, U niversity of $\mathrm{New}$ $\mathrm{H}$ ampshire, Durham, NH 03824.

varied from 18.0 to $38.3 \mathrm{~g}(0.6$ to 1.3 oz). PI 197691 and PI 270459 performed better than some of the commercial cultivars indicating their potential to be used as germplasm for breeding. A basket-weave trellising system which kept plants upright was tested. This made harvest easier and potentially can be used for tomatillo culture.

$\mathrm{T}$ omatillo or husk tomato is a herbaceous annual with indeterminate growth habit. It is native to C entral America where it is claimed that there is no acceptable substitute in making green sauce or salsa verde (Saray-M eza et al., 1978). Three species of the genus Physalis have edible fruit with higher contents of protein, ascorbic acid, nicotinic acid and solids than tomato (Yamaguchi, 1983). Physalis peruviana L. (cape gooseberry, uchuba) and P. pruinosa L. (ground cherry, husk tomato) are used as juice and jam fruit; P. ixocarpa is used as a vegetable or for sauces. Tomatillo isadaptableto growing conditions in northern latitudes and has potential commercial value due to the increased popularity of M exican food in the U nited States. In N ew H ampshire, most locally grown vegetables are sold retail through roadside stands and farmers' cooperativemarkets. Small farmers can profit from diversification and production of specialty crops such as tomatillo.

There have been studies on taxonomy and genetics (M enzel, 1951, Waterfall 1967, Quiros, 1984), selfincompatibility (Pandey, 1957), and development and growth of tomatillo (Cartujano-Escobar et al., 1985a, 1985b; M ulato-Brito et al., 1985). In Mexico many tomatillo cultivars are unnamed and considered criollas (native) and there are few named cultivars: 'D e M ilpa', with small and tart fruit, and 'Rendidora', developed by mass selection and having $35 \%$ of the total production in the country (SarayMeza et al., 1978). In the U nited States, studies on field production of to matillo were performed in L ouisiana (Moriconi et al., 1990) using seeds from a single fruit (cultivar name not mentioned). Wehavefound fivetomatillo cultivars available from commercial seed companies in N orth America. 'Rendidora' was discontinued in the seed market before 1991 (Whealy, 1992), and other than 'D e M ilpa', we do not know the origin of the other cultivars. Additionally, theU SD A-A RS Plant Genetic Resources $U$ nit at G eneva, N.Y., which holds the entire collection of Physalis in the U nited States, lists several P. ixocarpa accessions. The objectives of our study were to evaluate and conduct yield trials of tomatillo cultivars and available germplasm during the 1997 and 1998 growing seasons in $\mathrm{New} \mathrm{H}$ ampshire. Results of an observation plot using a basket-weave trellising system are also reported.

\section{Materials and methods}

1997 EXPeriment. On $1 \mathrm{M}$ ay 1997, fivetomatillo cultivarsfrom commercial seed companies ('T omatillo', 'Puebla Verde', 'D e M ilpa', 'Toma V erde' and 'T omatillo Purple') and 23 Physalis accessions were sown at the $\mathrm{U}$ niversity of $\mathrm{N}$ ew $\mathrm{H}$ ampshire research greenhouses. Each genotype wassown in a six-pack plug tray using Pro-mix BX soilless medium (Premier $\mathrm{H}$ orticulture Ltée. Rivière-du-Loup, $\mathrm{Q}$ uébec, Canada). Three seeds were sown in each cell except where germination rate was indicated to be low, in which case up to 10 seeds per cell were used. The trays were put under mist watering in a greenhouse held at $21^{\circ} \mathrm{C}$ $\left(70^{\circ} \mathrm{F}\right)$. When most of the seeds per tray germinated, the trays were moved into a greenhouseheld at $17^{\circ} \mathrm{C}\left(63^{\circ} \mathrm{F}\right)$ and plants were thinned to one per cell.

Genotypes were transplanted to the field at the Kingman Research Farm, D urham, N.H ., on 6 J une to a plot with $3 \%$ to $8 \%$ slopes and $\mathrm{H}$ ollisCharlton fine sandy loam $(C$ harlton $=$ coarse-loamy, mixed, mesic Entic $\mathrm{H}$ aplorthods; $\mathrm{H}$ ollis = loamy, mixed, mesic Entic Lithic $\mathrm{H}$ aplorthods). This plot had been broadcast-fertilized with $15 \mathrm{~N}-6.6 \mathrm{P}-12.5 \mathrm{~K}$ at a rate of 960 $\mathrm{kg} \cdot \mathrm{ha}^{-1}(857 \mathrm{lb} /$ acre) according to soil tests. Black plastic polyethylene mulch and drip irrigation (T-TAPE TSX, Rainflow I rrigation, East Earl, $\mathrm{Pa}$;; 8 mil [0.008 inch (0.2 mm]; emitters 20 $\mathrm{cm}$ ( 7.9 inches) apart) were used, with $1.8-\mathrm{m}(6-\mathrm{ft})$ spacing between rows, and $0.6-\mathrm{m}(2-\mathrm{ft})$ spacing between plants. T wo replicated plots of 10 plants per genotype in a completely randomized design were used. $M$ anual harvests were performed continuously from 20 Aug. to 25 Sept. 1997. A total of three harvests per plot were performed. After the first harvest, five of 
Table 1. T wenty-eight Physalis accessions and tomatillo cultivars grown in 1997 in N ew H ampshire.

\begin{tabular}{|c|c|c|}
\hline Accession $^{2}$ & Species & $\begin{array}{c}\text { Origin or } \\
\text { seed company }\end{array}$ \\
\hline G 30151 & P. ixocarpa & M exico \\
\hline G 30711 & P. ixocarpa & M exico \\
\hline G 31141 & P. sp. & Ecuador \\
\hline PI 194590 & P. sp. & Guatemala \\
\hline PI 203924 & P. sp. & M exico \\
\hline PI 232077 & P. peruviana (C ape gooseberry) & Namibia \\
\hline PI 270459 & P. ixocarpa & M exico \\
\hline PI 285705 & P. peruviana (Peruvian groundcherry) & Poland \\
\hline PI 290968 & P. ixocarpa & Argentina \\
\hline PI 512005 & P. ixocarpa & M exico \\
\hline PI 512006 & P. ixocarpa & M exico \\
\hline PI 512007 & P. ixocarpa & M exico \\
\hline PI 512008 & P. ixocarpa & M exico \\
\hline PI 512009 & P. ixocarpa & M exico \\
\hline PI 512010 & P. ixocarpa & M exico \\
\hline \multirow[t]{5}{*}{ PI 512011} & P. ixocarpa & M exico \\
\hline & P. ixocarpa (Tomatillo) & Burpee $^{y}$ \\
\hline & P. ixocarpa (Tomatillo Puebla Verde) & Gurney's ${ }^{x}$ \\
\hline & P. ixocarpa (Tomatillo D e M ilpa) & Johnny'sw \\
\hline & P. ixocarpa (Tomatillo Purple) & Johnny's \\
\hline
\end{tabular}

${ }^{\mathrm{z} A c c e s s i o n s ~ o b t a i n e d ~ f r o m ~ P l a n t ~ G e n e t i c ~ R e s o u r c e ~ U ~ n i t ~(G e n e v a, ~ N . Y .) ~}$

'W. Atlee Burpee and Co., Warminster, Pa.

${ }^{\times} G$ urney's Seed and N ursery C 0., Yankton, S.D.

w ohnny's Selected Seeds, Albion, M aine.

the Physalis accessions were selected, based on high yields, for subsequent harvests along with the commercial tomatillos. Two of selected accessions were listed as P. ixocarpa (PI 270459 and $\mathrm{PI} 291560)$, and the other three (PI 197691, PI 197692, and PI 309812) had no species identified. The rest of the accessions were found to have very small yields and no commercial value.

1998 EXPERIMENT. In 1998, five commercial tomatillo cultivarsplusthe five selected Physalis accessions were sown on $30 \mathrm{Apr}$. at the $U$ niversity of $\mathrm{N}$ ew $\mathrm{H}$ ampshire research greenhouses. The accession PI 197692 had a very low germination rate and did not have enough plants for field transplant. O n $4 \mathrm{~J}$ une a total of nine genotypes were transplanted to thefield at theKingman Research Farm into black plastic mulch on 15-cm (6-inch) raised beds fitted with drip irrigation. Before planting the plot was broadcast fertilized with $15 \mathrm{~N}$ 3.5P-10K at a rate of $674 \mathrm{~kg} \cdot \mathrm{ha}^{-1}(602$ $\mathrm{lb} /$ acre) according to soil tests. Two replicated plots of 10 plants per genotype in a completely randomized design were used. Spacing between plots

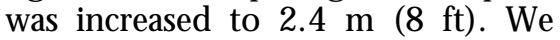
selected five plants per genotype and recorded the date of first open flower, growth habit (40 d after transplant), mature fruit colors and fruit shape (three fruit per plant), and fruit diameter (measured on 10 fruit per plant using digital calipers). Three manual harvests per plot were performed between 26 Aug. and 29 Sept. 1998.

During both years, data were recorded on total fruit weight and number of fruit per plot. Total fruit weight was extrapolated to yield per hectare. Average fruit weight was calculated. Analyses of variance of total yield, fruit number and average fruit weight per plant over both years were performed using SAS (SAS I nstitute I nc., 1990). $M$ ean separation was performed using the least significant difference (LSD) test.

BASKet-WEAVE TRELLIS EXPERIMENT.
An observation plot of 10 plants of 'T omatillo' with a basket-weave trellis using stakes and twine (Konsler and Gardner, 1990) was included in the 1998 experiment. This plot was harvested threetimesalong with the other plots, and the time required to harvest was recorded.

\section{Results and discussion}

Growth AND DeVELOPMENT. The 28 Physalisgenotypes grown in 1997 are listed in T able 1. Plants grew very vigorously, eventually covering the space between rows. The only pest problem encountered was northern corn rootworm (Diabrotica barberi Smith \& L awrence) early in the season which was controlled with an application of carbaryl as a $10 \%$ dust. M ost genotypes had indeterminate growth habit which became prostrate by the end of the season, making harvest very laborious. The only genotype with an upright growth habit was 'Purple Tomatillo'. 
Table 2. Description of nine tomatillo genotypes grown in 1997 and 1998 in $\mathrm{N}$ ew H ampshire.

\begin{tabular}{|c|c|c|c|c|c|}
\hline $\begin{array}{l}\text { Cultivar or } \\
\text { accession }\end{array}$ & $\begin{array}{c}\text { Date of } \\
\text { first flower } \\
\text { (1998) }\end{array}$ & $\begin{array}{c}\text { U pright } \\
\text { habit }\end{array}$ & $\begin{array}{c}\text { M ature } \\
\text { fruit } \\
\text { colors }^{2}\end{array}$ & $\begin{array}{c}\text { Fruit } \\
\text { shape }^{y}\end{array}$ & $\begin{array}{l}\text { Fruit } \\
\text { diam } \\
(\mathrm{cm})^{\mathrm{x}}\end{array}$ \\
\hline Tomatillo & 8 June & No & $G, Y$ & $\mathrm{R}, \mathrm{OV}$ & 3.3 \\
\hline Puebla Verde & 8 J une & No & $G, Y$ & $\mathrm{R}, \mathrm{O} v, \mathrm{Ob}$ & 3.4 \\
\hline Toma Verde & $8 \mathrm{~J}$ une & No & $G, Y$ & $\mathrm{R}, \mathrm{O} v, \mathrm{Ob}$ & 3.3 \\
\hline De M ilpa & 24 June & No & $G, G / P$ & $\mathrm{R}, \mathrm{O} v, \mathrm{Ob}$ & 2.6 \\
\hline Purple & 15 June & Yes & $G, P$ & $\mathrm{R}, \mathrm{O} \mathrm{v}, \mathrm{Ob}$ & 2.9 \\
\hline PI 197691 & 12 June & No & $G, Y$ & $\mathrm{R}, \mathrm{OV}$ & 3.3 \\
\hline PI 270459 & 8 J une & No & $G, Y$ & $\mathrm{R}, \mathrm{Ob}$ & 3.7 \\
\hline PI 291560 & $8 \mathrm{~J}$ une & No & $G, Y$ & $\mathrm{R}, \mathrm{O} v, \mathrm{Ob}$ & 2.9 \\
\hline PI 309812 & 19 June & No & $G, Y$ & Ov & 4.5 \\
\hline
\end{tabular}

${ }^{{ }^{\prime} G}=$ green; $Y=$ yellow; $P=$ purple; $G / P=$ green/ purple.

${ }^{\mathrm{R}} \mathrm{R}=$ round; $\mathrm{OV}=$ ovate; $\mathrm{Ob}=$ oblate.

${ }^{x}$ Average of 50 fruit, $2.54 \mathrm{~cm}=1.0$ inch.

T able 3. Analyses of variance for total fruit weight, number of fruit per plant and average fruit weight of nine tomatillo genotypes over 1997 and 1998 in N ew H ampshire.

\begin{tabular}{|c|c|c|c|c|}
\hline \multirow[b]{2}{*}{ Source } & \multirow[b]{2}{*}{ df } & \multicolumn{3}{|c|}{ Mean square } \\
\hline & & $\begin{array}{c}\text { Total } \\
\text { fruit wt } \\
\left(t \cdot h a^{-1}\right)^{z}\end{array}$ & $\begin{array}{l}\text { Fruit/ } \\
\text { plant } \\
\text { (no.) }\end{array}$ & $\begin{array}{c}\text { Avg fruit } \\
\text { wt } \\
(g)^{y}\end{array}$ \\
\hline Year & 1 & 149.89 & $2048715.11^{*}$ & $245.23^{* * *}$ \\
\hline Cultivar & 8 & $620.59^{* * *}$ & $1742602.65^{* * *}$ & $219.05^{* * *}$ \\
\hline Year $\times$ cultivar & 8 & 70.42 & 113213.36 & 13.78 \\
\hline Error & 18 & 95.79 & 282131.67 & 13.91 \\
\hline Total & 36 & & & \\
\hline CV(\%) & & 21.99 & 29.73 & 12.8 \\
\hline
\end{tabular}

z2.24 th ha ${ }^{-1}=1.0$ ton/ acre.

y28.35 g=1.0 oz.

${ }^{*, * * *}$ Significant at $\mathrm{P}=0.05$ or 0.001 , respectively.

In 1998 thefivecommercial tomatillo cultivars and four Physalis accessions with comparable yields were grown. In this season the only pest encountered was tomato hornworm (M anduca quinquemaculata $\mathrm{H}$ aworth) which was controlled with an application of Bacillusthuringensis Berliner subsp. kurstaki (Thuricide, BonideProductsI nc., Yorkville, N .Y.). The wider spacing used between rows this year facilitated cultural operations and harvesting.

A description of the genotypes grown in 1998 can be found in Table 2 . There was variation in the start of flowering. Some genotypes started flowering soon after transplanting, about $40 \mathrm{~d}$ after being sown. The latest was' $D$ eM ilpa', which started to flower when plants were about $55 \mathrm{~d}$ old. Although self-incompatibility has been reported in P. ixocarpa (Pandey, 1957), we obtained fruit with viable seeds by self pollinating emasculated flowers, and also from plants grown in the greenhouse in absence of pollinating insects. $M$ ature fruit colorsweregreen, purple, green/ purple or yellow. Fruit shapes were either round, ovate or oblate. Average fruit diameters varied from $2.6 \mathrm{~cm}$ (1.02 inches) in 'De M ilpa', to $3.7 \mathrm{~cm}$ (1.45 inches) in PI 270459.

FRUIT YIELD. Fruit were considered ready for harvest when they had filled completely or were protruding from the husk. Partially rotted fruit and some of the largest fruit which were cracked were not included when recording total fruit weight. Each of the three harvests was spread over a period of time so statistical analyses were performed with the total data per genotype. The combined analysis of variance for the 2 years for total fruit weight, fruit number per plant and average fruit weight is shown on $T$ able 3. There were statistically significant differences between tomatillo genotypes for all three traits. Statistically significant differences between the 2 years were found for fruit number and average fruit weight per genotype.

Results for total fruit weight per genotype, fruit number per plant and average fruit weight areshown in T able 4. We found all tomatillo genotypesto be extremely productive. Total yield ranged between 29.7 to $63.7 \mathrm{t} \cdot \mathrm{ha}^{-1}$ (13.3 to 28.4 ton/ acre). This was much higher than previous reports of $15 \mathrm{t} \cdot \mathrm{ha}^{-1}$ ( 6.7 ton/ acre) for criollatypes and $25 \mathrm{t}^{\mathrm{h}} \mathrm{ha}^{-1}$ (11.2 ton/ acre) for 'Rendidora' in M exico, and $13.5 \mathrm{t} \cdot \mathrm{ha}^{-1}$ ( 6 ton/ acre) in Louisiana (M oriconi et al., 1990). These authors reported yield losses of 20 to $40 \%$ due to plant viruses and lepidopterous insects. Another possibility for the differences in yield is that in our case, due to the amount of time and labor required for harvest, we found it was impossible to harvest all fruit when they were still green and at their prime marketable stage. Fruit that had already fallen off the plants were also picked up unless they were soft or rotten, and considered in the total yield.

0 ver the 2 years, 'T omatillo' had the highest yields, followed by $\mathrm{PI}$ 197691, 'Puebla Verde', PI 270459, 'Toma Verde', 'Purple Tomatillo', PI 291560, 'D e M ilpa', and PI 309812. 
T able 4. T otal fruit weight, fruit number per plant, and average fruit weight of nine tomatillo genotypes grown in 1997 and 1998 in $\mathrm{N}$ ew $\mathrm{H}$ ampshire.

\begin{tabular}{|c|c|c|c|c|c|c|c|c|c|}
\hline \multirow{2}{*}{$\begin{array}{l}\text { Cultivar or } \\
\text { accession }\end{array}$} & \multicolumn{3}{|c|}{$\begin{array}{c}\text { Total } \\
\text { fruit } \\
\text { wt }^{\mathbf{z}} \\
\left(\mathrm{t} \cdot \mathrm{ha}^{-1}\right)^{\mathrm{w}}\end{array}$} & \multicolumn{3}{|c|}{$\begin{array}{l}\text { F ruit/ } \\
\text { plant } \\
\text { (no.) }\end{array}$} & \multicolumn{3}{|c|}{$\begin{array}{c}\text { Avg } \\
\text { fruit } \\
w^{x} \\
(g)^{v}\end{array}$} \\
\hline & 1997 & 1998 & Avg & 1997 & 1998 & Avg & 1997 & 1998 & Avg \\
\hline Tomatillo & 65.1 & 62.3 & $63.7 \mathrm{a}$ & 204 & 212 & $208 b$ & 34.3 & 31.9 & $33.1 \mathrm{bc}$ \\
\hline Puebla Verde & 50.7 & 61.2 & $55.9 \mathrm{abc}$ & 137 & 191 & $164 \mathrm{~b}$ & 41.8 & 34.7 & $38.3 a b$ \\
\hline Toma Verde & 36.0 & 49.7 & $42.9 \mathrm{cde}$ & 116 & 185 & $151 b c$ & 33.5 & 28.6 & $31.1 \mathrm{~cd}$ \\
\hline De M ilpa & 22.1 & 38.8 & $30.5 \mathrm{e}$ & 130 & 238 & $184 \mathrm{~b}$ & 18.3 & 17.6 & $18.0 \mathrm{~g}$ \\
\hline Purple & 33.1 & 42.1 & $37.6 \mathrm{de}$ & 120 & 189 & $155 b c$ & 30.0 & 24.1 & $27.1 \mathrm{de}$ \\
\hline PI 197691 & 58.9 & 58.6 & $58.8 \mathrm{ab}$ & 317 & 343 & $330 a$ & 21.1 & 19.7 & $20.4 \mathrm{fg}$ \\
\hline PI 270459 & 48.4 & 42.9 & $45.6 \mathrm{bcd}$ & 137 & 183 & $160 \mathrm{bc}$ & 38.1 & 25.2 & $31.7 \mathrm{~cd}$ \\
\hline PI 291560 & 36.5 & 35.5 & 36.0 de & 148 & 200 & $174 \mathrm{~b}$ & 27.3 & 20.0 & 23.7 ef \\
\hline PI 309812 & 31.5 & 27.9 & $29.7 \mathrm{e}$ & 84 & 83 & $83 c$ & 41.0 & 36.7 & 38.8 a \\
\hline
\end{tabular}

zM eans not followed by the same letter are significantly different with $L S D=14.5$.

YM eans not followed by the same letter are significantly different with $L S D=78.9$.

${ }^{\times} M$ eans not followed by the same letter are significantly different with $L S D=5.5$.

w2.24 $\mathrm{t} \cdot \mathrm{ha}^{-1}=1.0 \mathrm{ton} / \mathrm{acre}$.

v28.35 g = $1.0 \mathrm{oz}$

In terms of fruit weight PI 309812 had the highest average, followed by 'Puebla Verde', 'Tomatillo', PI 270459, 'T omaVerde', 'PurpleT omatillo', PI 291560, PI 197691, and 'De Milpa'. 'D e M ilpa' had the smallest fruit, and also the lowest yield of all commercial cultivars. $\mathrm{H}$ owever itsfruit do not crack and they stored best, remaining green and firm for up to 2 weeks, even at room temperature. 0 ur results indicate the potential of some tomatillo accessions such as PI 19761 and $\mathrm{PI} 270459$ for use as germplasm to develop commercial cultivars.

D uring the first year, we noticed that the biggest constraint for tomatillo production was the labor-intensive harvest dueto theprostrategrowth of plants. In 1998, we included an observation plot of 10 'Tomatillo' plants using a basket-weave trellising system. We thought that this system, often used with tomatoes (Lycopersicon esculentum M ill.), could make harvest easier by keeping plants upright. The first two harvests of this plot were timed and compared to the time required to harvest another plot of the same genotype without trellising. We found that on average, the time required to harvest 100 fruit was $2 \mathrm{~h} 37$ min with the trellis versus $3 \mathrm{~h} 13 \mathrm{~min}$ without. More fruit were harvested from the trellised plot but total fruit weight was slightly lower, resulting in an average fruit weight of $28.4 \mathrm{~g}(1 \mathrm{oz})$ with the trellis versus $32.7 \mathrm{~g} \mathrm{(1.2} \mathrm{oz)}$ without. M ore replications would be needed to verify if these differences are consistent and statistically significant. $\mathrm{H}$ owever, in this initial study we noticed that harvest was more comfortableand easier with trellised plantsand fruit that had fallen off the plants were not hidden under foliage. These results indicate the potential use for this trellising system for tomatillo culture.

\section{Literature cited}

Cartujano-Escobar, F., L.J Jankiewicz, V.M . Fernandez-O rduna, and J. M ulato-Brito. 1985a. The development of the husk tomato plant (Physalisixocarpa B rot.) I. Aerial vegetative parts. Acta Soc. Bot. Poland 54:327-338.

Cartujano-E scobar, F., L.J Jankiewicz, V.M . Fernandez-O rduna, and J. M ulato-Brito. $1985 \mathrm{~b}$. The development of the husk tomato plant (Physalisixocarpa Brot.) I. Reproductive parts. Acta Soc. Bot. Poland 54:339-349.

Konsler T.R and R.G. Gardner. 1990. Commercial production of staked tomatoes in N orth Carolina. N.C. State U niv. Agr. Ext. Serv. Publ. AG-405.

M enzel, M . 1951. The cytotaxonomy and genetics of Physalis. Proc. Amer. Philosophycal. Soc. 95:132-183.
M oriconi, D .N ., M .C. Rush, and H . Flores. 1990. Tomatillo: A potential vegetable crop for Louisiana, p. 407-413. In: J. Janick and J.E. Simon (eds.). Advances in new crops. Timber Press, Portland, 0 re.

M ulato-Brito, J., L. Jankiewicz, V.M. Fernandez-O rduna, F. C artujano-Escobar, and L.M. Serrano-C ovarrubias. 1985. Growth, fructification and plastochron index of the husk tomato plant (Physalis ixocarpa Brot.). Acta Soc. Bot. Poland. 54:195-206.

Pandey, K.K. 1957. Genetics of self-incompatibility system in Physalis ixocarpa Brot.: A new system. Amer. J. Bot. 44:879887.

Q uiros, C.F. 1984. O verview of the genetics and breeding of husk tomato. H ortScience 19:872-874.

Saray-M eza, C.R., A. Palacios, and E. Villanueva. 1978. Rendidora, nueva variedad de tomate de cáscara. El C ampo 54:17-21.

SAS Institute I nc. 1990. SAS procedures guide. version 6. 3rd ed. Cary, N.C.

Waterfall, U .T. 1967. Physalis in M exico, Central America and the West Indies. Rhodora 69:82-120.

Whealy, K. 1992. Garden seed inventory. 3rd ed. Seed Saver Publ., D ecorah, I owa.

Yamaguchi, M. 1983. World vegetables, principles, production and nutritive values. Avi., Westport, Conn. 